COSTA, M.R.G.F. et al. Uso do fogo em pastagens naturais. PUBVET, Londrina, V. 5, N. 9, Ed. 156, Art. 1050, 2011.

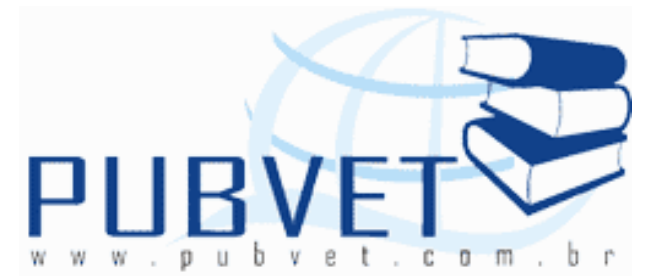

PUBVET, Publicações em Medicina Veterinária e Zootecnia.

\title{
Uso do fogo em pastagens naturais
}

Marcus Roberto Góes Ferreira Costa ${ }^{1}$; Magno José Duarte Cândido ${ }^{2}$, Maria Socorro de Souza Carneiro ${ }^{2}$, Luiz Barreto de Morais Neto ${ }^{1}$, João Avelar Magalhães ${ }^{3}$, Newton de Lucena Costa ${ }^{4}$

${ }^{1}$ Eng. Agrônomo, M.Sc., Doutorando em Zootecnia, UFC, Fortaleza, Ceará.

${ }^{2}$ Professores do Programa de Pós-Graduação em Zootecnia da UFC.

${ }^{3}$ Med. Veterinário, D.Sc., Embrapa Meio Norte. Parnaíba, Piauí.

${ }^{4}$ Eng. Agrônomo, M.Sc., Embrapa Roraima. Doutorando em Agronomia/Produção Vegetal, UFPR, Curitiba, Paraná.

\section{Resumo}

O uso racional do fogo em pastagens naturais pode ser benéfico para os atributos químicos do solo, mineralizando seus nutrientes, tornando-os disponíveis para as plantas forrageiras e favorecendo seu crescimento. Sem os devidos cuidados a queima pode promover uma redução nos teores de matéria orgânica do solo, fato que reduz algumas qualidades físicas e biológicas. 0 fogo nem sempre promove aumento na produção e qualidade da forragem, sendo a resposta diretamente relacionada com a composição florística da pastagem. Quando há espécies com grande valor forrageiro tolerantes ao fogo, essa prática pode ser benéfica quanto à qualidade da forragem, mas, quando as espécies forem de baixa palatabilidade e baixo valor nutritivo, a qualidade da pastagem pode ser reduzida pelo uso do fogo. $O$ efeito do fogo em 
COSTA, M.R.G.F. et al. Uso do fogo em pastagens naturais. PUBVET, Londrina, V. 5, N. 9, Ed. 156, Art. 1050, 2011.

pastagens naturais sobre o desempenho animal é uma resposta direta à modificação na qualidade da forragem em virtude da indução do perfilhamento, o que eleva o valor nutritivo da forragem, promovendo assim, elevação no ganho de peso dos animais. Este efeito pode ser anulado quando há alterações no comportamento ingestivo dos animais, como conseqüência da mudança indesejável da composição florística da pastagem natural. A utilização do fogo, como prática de manejo de pastagens, deve ser precedida de uma análise sobre a sua eficácia, eficiência e sustentabilidade, em termos de melhoria das características físico-químicas do solo, da produção animal e da produtividade, qualidade e persistência da pastagem.

Palavras-chave: produção de forragem, composição química, fogo, fertilidade do solo

\section{Burning in natural pastures}

\section{Abstract}

The rational use of the fire in natural pastures can be beneficial for the soil chemical characteristics, providing the mineralization of minerals, and increased them available for the plants, beyond promoting this higher growth, however without cares can promote a reduction in the soil organic matter contents. In natural pastures the use of the fire does not always promote increase in the forage yield and quality. The response of natural grasses to burn depends straightly of the floristic composition. For the tolerant species to the fire, that practice can be beneficial and improve the forage quality, but, when the tolerant species to the fire present low palatability and nutritious value, the quality of the grass is limited by the fire. The effect of burned natural pastures on the animal performance is a direct response to the changes in the forage quality as consequence of higher grass tillering that supply excellent nutritive forage. This effect can be annulled when there is a modification in the animal intake behavior as a consequence of the undesirable composition floristic changes. The utilization of the fire, as routine practice of 
COSTA, M.R.G.F. et al. Uso do fogo em pastagens naturais. PUBVET, Londrina, V. 5, N. 9, Ed. 156, Art. 1050, 2011.

pasture management, should be preceded of an analysis about its efficacy, efficiency and sustainability, with respect to improvement of the soil physicalchemistry characteristics, animal production, and productivity, quality and pasture persistence.

Keywords: forage yields, chemical composition, fire, soil fertility

\section{Introdução}

O fogo é considerado a mais antiga fonte de energia natural dominada pelo homem e um fenômeno natural que sempre existiu na superfície do planeta. Nos primórdios das civilizações, a principal fonte de ignição eram as descargas elétricas ocorridas durante as tempestades, o que gerava fogo a partir da queima da vegetação natural. $O$ fogo passou a ser usado como fonte de calor para o aquecimento e preparo de alimentos, possibilitando a fixação de tribos nômades nas mais diversas regiões do globo.

O uso do fogo em áreas de pastagens teve início quando pastores perceberam que a vegetação das áreas recentemente queimadas era mais nutritiva e preferida pelos animais, sendo a partir de então, uma prática rotineira utilizada no manejo de pastagens, notadamente no final da estação de crescimento (SOARES, 1995).

A queima é a prática agrícola mais econômica no preparo do solo para o plantio e em áreas florestais é utilizada para reduzir o material vegetal, o que possibilita a entrada de máquinas e melhores condições para a germinação das sementes. $O$ fogo controlado também é utilizado para prevenir incêndios, pois reduz o material combustível, uma vez que este é o único elemento do triângulo do fogo (combustível, comburentes e calor) que pode ser dominado pelo homem.

Com relação aos nutrientes do solo, o fogo pode promover uma redução em seus teores, mais em contrapartida, aumenta a sua disponibilidade em virtude da mineralização. Contudo, quando utilizado com freqüência e em alta intensidade promove o empobrecimento do solo, uma vez que a combustão nunca é completa e gera, além de água, dióxido de carbono e calor, além de monóxido de carbono e outros produtos considerados poluentes, como hidrocarbonetos e óxido de nitrogênio.

Diante o exposto, essa revisão analisa o efeito do fogo em pastagens naturais, buscando apresentar seus benefícios e malefícios e as formas mais adequadas para o seu uso. 
COSTA, M.R.G.F. et al. Uso do fogo em pastagens naturais. PUBVET, Londrina, V. 5, N. 9, Ed. 156, Art. 1050, 2011.

\section{Efeito do fogo sobre as características do solo sob pastagens naturais}

Na Austrália, a prática do fogo com fins agrícolas foi implantada por volta de 1700, pelos colonizadores britânicos como forma de remover florestas para o plantio de cultivos agrícolas e pastagens (CHENEY; SULLIVAN, 2008). Quando se decide utilizar a técnica do uso do fogo no manejo de pastagens, seja natural ou cultivada, deve-se estar atento aos efeitos sobre as características químicas e físicas do solo, pois o fogo exerce ação direta sobre a sua umidade, teor de matéria orgânica e nutrientes. De acordo com Raison (1979) a queima de pastagens é um dos métodos de manejo cujos efeitos no solo têm sido negligenciados nas pesquisas, pois são realizadas em áreas pouco representativas e sem histórico conhecido de queimadas, induzindo a conclusões precipitadas ou equivocadas. Em áreas onde o uso desta prática é sistêmico, a quantidade e a composição dos nutrientes que reciclam no solo dependem diretamente do regime de queimadas, sendo seus efeitos evidenciados através da incorporação de cinzas, redução de cobertura e aquecimento do solo.

Um efeito direto do fogo sobre o solo é a elevação da temperatura, a qual pode promover aumentos na taxa de decomposição dos resíduos e na mineralização da matéria orgânica (MO) e, consequentemente, a disponibilização de nutrientes que se encontravam complexados (SCHACHT et al., 1996). Os elementos minerais que se tornam mais facilmente disponíveis com a ação do calor sobre a $\mathrm{MO}$ são: $\mathrm{NH}_{4}{ }^{+}, \mathrm{P}$ inorgânico, Na, Ca, Mg e parte do K (GIRARDI-DEIRO et al., 1994). Para Arias (1963) e Villares (1966) o fogo como ferramenta de manejo pode ser positivo devido à sua ação decompositora que ocorre a um nível inferior ao da vegetação. Um dos mais significativos efeitos do fogo controlado sobre o ecossistema é a mineralização da MO acumulada sobre o solo florestal, a qual representa o elo entre o orgânico e inorgânico, sendo tão importante para a vida das plantas, quanto a fotossíntese que interliga o inorgânico e orgânico (SOARES, 1995).

Contrariando os efeitos positivo do uso do fogo em pastagens naturais sobre a MO, Moore (1960), relatou que após trinta anos de trabalhos com queima de pastagens em solo sob vegetação de savana, na Nigéria, os teores de MO apresentaram-se $30 \%$ mais altos nas parcelas com queima leve (início do período seco) do que naquelas com queima severa (fim do período seco). Corroborando com esses resultados Wright et al. (1976) encontraram perdas de MO do solo, variando de 0,08 a $0,56 \%$ para áreas com declividade moderada (8 a 20\%) e íngreme (37 a 
COSTA, M.R.G.F. et al. Uso do fogo em pastagens naturais. PUBVET, Londrina, V. 5, N. 9, Ed. 156, Art. 1050, 2011.

$61 \%)$, respectivamente, mostrando que além do fogo o relevo também tem efeito sobre a MO do solo.

De acordo com Soares (1995), o empobrecimento do solo através do fogo pode ocorrer basicamente em duas situações: primeira, em incêndios de alta intensidade, que queimam, volatilizam ou dispersam quase toda a MO e a maior parte dos nutrientes e, segunda quando do solo recebe queimas sucessivas e com isso seu estoque de nutrientes é reduzido gradualmente. Em áreas florestais, onde os ciclos são longos, a segunda situação raramente ocorre, pois o solo recupera todo seu potencial antes do final da rotação. No sul dos Estados Unidos, por exemplo, solos com cobertura florestal, submetidos a queima controlada periódica por mais de 50 anos, não mostraram nenhuma deterioração ou diminuição da fertilidade.

O fogo tem influência direta nas características químicas do solo. Ao longo dos anos seu uso constante em pastagens pode promover o decréscimo da capacidade de troca de cátions (CTC) e uma elevação no pH do solo em conseqüência do efeito das cinzas que reduzem temporariamente os teores de alumínio e de ácidos orgânicos e, ao mesmo tempo, aumentam a saturação de bases na superfície do solo (GIOVANNINI; LUCCHESI, 1997). Heringer (2000) estudou o efeito do fogo por longo período sobre parâmetros do solo e vegetação de uma pastagem natural nos campos sulinos brasileiros, utilizando diferentes alternativas de manejo sob condições de pastejo: sem queima e sem roçada há 32 anos; roçada anual há 32 anos; melhoramento da pastagem nativa há sete anos; melhoramento da pastagem nativa há 24 anos e, queima bienal há mais de 100 anos. A queima resultou em maiores teores e saturação de alumínio e maior acidez potencial, bem como menores teores de magnésio na camada superficial do solo; a roçagem reduziu a acidez potencial e aumentou a saturação de bases na superfície do solo. As queimadas em pastagens naturais, na região de elevada altitude dos campos sul brasileiros, deve ser evitada como prática de manejo rotineira, pois deteriora as características do solo e reduz o potencial produtivo da vegetação nativa.

Avaliando as características de um Latossolo Vermelho, sob pastagem natural, em Guaíba, RS, Heringer et al. (2002) relataram que o teor de Al trocável, a acidez potencial e a saturação por Al tenderam a ser sempre maiores no solo de pastagem nativa quando submetido ao uso do fogo, quando comparado a áreas não queimadas. A saturação de bases por alumínio, nas áreas apenas roçadas foi menor na camada de 
COSTA, M.R.G.F. et al. Uso do fogo em pastagens naturais. PUBVET, Londrina, V. 5, N. 9, Ed. 156, Art. 1050, 2011.

0-5 cm, em relação aos outros tratamentos submetidos a queimadas, se assemelhando a estes nas camadas mais profundas. Segundo Jacques (2002) a queima resultou em maiores teores e saturação de alumínio, e maior acidez potencial do solo, bem como menores teores de magnésio na camada superficial. Para Heringer \& Jacques (2002), a queima freqüente e contínua das pastagens naturais deve ser evitada, pois promove a redução nos teores de magnésio, aumenta a acidez potencial e reduz a cobertura e umidade nas camadas superficiais do solo, comparativamente às práticas de manejo sem queima.

Com relação aos nutrientes do solo sob uma floresta, deve-se distinguir a quantidade total (a maior parte sob forma orgânica) e a disponível (mineralizada). Quando se faz uma queima controlada, embora a quantidade total de nutrientes diminua, a quantidade disponível ou mineralizada aumenta, sendo verificados aumentos de mais de $100 \%$ nos teores de N, P, K, Ca e Mg mineralizados após o fogo, sendo isto uma vantagem do uso da queima. Uma vez que as plantas somente absorvem nutrientes mineralizados, sendo natural que elas cresçam mais rapidamente em áreas queimadas (SOARES, 1995). Avaliando os atributos químicos do solo de campos nativos do sul do Brasil, Rheinheimer et al. (2003) relataram redução nos teores de nitrogênio total após a queima, diminuindo nos meses subseqüentes, inclusive não retornando às concentrações naturais no fim do período de um ano. As possíveis perdas de $\mathrm{N}$ por volatilização podem ser compensadas por ganhos estimulados pelo aumento na atividade bacteriana do solo após a queima. As concentrações de Ca e Mg apresentaram comportamento inverso; a queima provocou aumentos em suas concentrações, porém rapidamente retornaram aos valores iniciais e inferiram que o aumento na concentração desses cátions está vinculado à liberação de óxidos nas cinzas, estando de acordo com o que acontece em outros ambientes.

Em pastagens naturais da região do Pantanal arenoso, o efeito do fogo quinze dias após a queima apresentou elevação do $\mathrm{pH}$ se situando entre 5,5 e 5,9, apresentando diferença de acordo com a profundidade. Com relação à CTC, da soma de bases trocáveis, da saturação em bases e do conteúdo de fósforo, todas essas variáveis também apresentaram elevação após a queima, fato explicado devido ao efeito fertilizador das cinzas depositadas na superfície do solo após a queimada (FERNANDES; FERNANDES, 2002). Esses resultados vão ao encontro dos relatados por Fernandez et al. (1997) que reportaram para um ecossistema de vegetação 
COSTA, M.R.G.F. et al. Uso do fogo em pastagens naturais. PUBVET, Londrina, V. 5, N. 9, Ed. 156, Art. 1050, 2011.

aberta (savanas), logo após a queima, aumento do $\mathrm{pH}$ e dos teores de $\mathrm{P}, \mathrm{Ca}, \mathrm{Mg}$, e $\mathrm{K}$ nas camadas superficiais do solo ou variação significativa nos teores de outros elementos, sendo esses incrementos atribuídos às cinzas, o que pode acelerar a produção primária em certos ecossistemas. As concentrações de carbono e nitrogênio da biomassa microbiana do solo também foram aumentadas pela queima, enquanto que a relação carbono/nitrogênio do solo diminuiu, o que pode significar um aumento nas taxas de mineralização da MO do solo (FERNANDES et al., 2007). Nardoto \& Bustamante (2003) observaram resultados similares para pastagens naturais em áreas de cerrado, no Centro-Oeste brasileiro, sendo verificado maior pH na área queimada e uma elevação na concentração de nitrogênio amoniacal, além de pequenos acúmulos de nitrogênio nítrico no solo, contudo apenas por curto período na estação chuvosa. As áreas queimadas e não queimadas apresentaram um mesmo padrão de mineralização/imobilização, mas com menor produção anual de $\mathrm{N}$ mineral na área queimada $\left(14,7 \mathrm{~kg} \cdot \mathrm{ha}^{-1}\right.$. ano ${ }^{-1}$ na área sem queima e $3,8 \mathrm{~kg}$. ha- ${ }^{-1}$.ano-1 na área queimada), um ano após a queima.

\section{Qualidade e produção das pastagens naturais sob efeito do fogo}

A queima das pastagens naturais, visando à melhoria da sua qualidade, ocorre desde os primórdios das civilizações, quando índios queimavam os pastos ao redor das tribos para atrair herbívoros em busca de forragem de melhor qualidade, facilitando a caça. Na Europa também se fez o uso do fogo em suas pastagens naturais com os objetivos similares, a obtenção de um pasto de melhor qualidade e melhor valor nutricional. Com a colonização dos novos continentes, essa prática espalhou-se amplamente, concomitantemente com a pecuária.

Um aspecto de grande importância a ser observado em pastagens naturais, determinante no sucesso da atividade, é a qualidade da forragem que está intrinsecamente ligada à sua composição florística. O uso do fogo em pastagens naturais tem como justificativa a melhoria na qualidade da forragem, decorrente da rebrotação após o fogo. Alguns autores confirmam essa justificativa. Para Svejcar (1989), a elevação da qualidade de pastagens naturais relaciona-se com a ação do fogo sobre as espécies dominantes, mudança na dieta após a queima, ação do fogo na estrutura da vegetação e especialmente na redução do material morto. O aumento da qualidade do pasto natural após a queima pode ser atribuído à maior oferta de Ca, 
COSTA, M.R.G.F. et al. Uso do fogo em pastagens naturais. PUBVET, Londrina, V. 5, N. 9, Ed. 156, Art. 1050, 2011.

Mg, P e K para as plantas, promovendo uma elevação temporária em seus teores nos tecidos verdes, no entanto, tendem a retornar aos níveis originais ao passar do tempo (SACIDO; CAUHÉPÉ, 1998). Hodgson (1990) citou que o crescimento das plantas depende de um contínuo suprimento de nutrientes no solo e cada elemento mineral está envolvido em um movimento cíclico do solo para a planta, das plantas para os animais e depois, destes para o solo. Em pastagens produtivas e bem adubadas da Nova Zelândia há uma extração média anual de $180 \mathrm{~kg} \cdot \mathrm{ha}^{-1}$ de N, $20 \mathrm{~kg} \cdot \mathrm{ha}^{-1}$ de P e $140 \mathrm{~kg} \cdot \mathrm{ha}^{-1}$ de $\mathrm{K}$, sendo, portanto, dependentes de um forte aporte de nutrientes.

Com relação ao aumento na qualidade da forragem, tem-se observado que o efeito é temporário, pois com a maturação da forragem os teores de proteína bruta (PB) e a digestibilidade da matéria seca (MS) são reduzidos, como conseqüência da aceleração do ciclo de desenvolvimento das gramíneas, as quais atingem o estádio reprodutivo antecipadamente, perdendo a qualidade (BRÂNCIO et al., 1997; McATEE et al., 1979).

Com relação ao efeito do fogo sobre a composição florística, Cardoso et al. (2003) verificaram que em pastagens naturais no ecossistema do Pantanal, a queima influenciou a freqüência e o número de espécies gramíneo-lenhosas quando comparada à área sem queima, tendo as gramíneas apresentado, em geral, o mesmo número de espécies nas duas áreas. Com relação ao grupo de ciperáceas e dicotiledôneas, constatou-se aumento no número e na freqüência das espécies após a queimada.

Embora a freqüência seja um atributo pouco sensível na identificação de mudanças na vegetação, ela pode ser utilizada como critério para avaliar o quanto uma espécie tem variação em sua distribuição e abundância após o fogo, deste modo pode-se estimar a qualidade da pastagem em relação à freqüência de espécie de alto valor forrageiro (FRANGI et al., 1980). Apesar da influência da queima, não foi constatada a eliminação de espécies anteriormente presentes ou o surgimento de novas nas áreas de pastagens naturais do bioma Pantanal avaliadas. Por outro lado, a queima promoveu uma diminuição na produção de biomassa por área total quando comparadas com áreas sem queima.

Em estudo sobre o efeito do fogo sobre a vegetação de pastagem nativa dos campos sulinos brasileiros, Heringer (2000) concluiu que a queima favorece as 
COSTA, M.R.G.F. et al. Uso do fogo em pastagens naturais. PUBVET, Londrina, V. 5, N. 9, Ed. 156, Art. 1050, 2011.

Andropogonaceas e Piptochaetium montevidense, em detrimento de gramíneas e leguminosas de hábitos rasteiros e de ciperáceas, reduzindo a sua biodiversidade.

Com relação à produção de forragem, Heringer (2000) relatou que o fogo promoveu um efeito positivo na taxa de alongamento foliar de Andropogon laeralis, gramínea nativa das pastagens naturais na região Sul do Brasil e com isso houve uma maior produção de MS, sendo este comportamento atribuído a uma maior disponibilização de nutrientes pela queima. Heringer \& Jacques (2002) avaliaram uma zona de transição entre campo e mata com grande cobertura e dominância de gramíneas cespitosas dos gêneros Aristida, Andropogon, Schizachyrium, Elyonurus e Trachypogon, todas pastejadas e manejadas sob distintas formas: sem queima e sem roçada há 32 anos; sem queima há 32 anos e roçada anualmente; melhorada há sete anos; melhorada há 24 anos; queimada numa freqüência bienal há mais de 100 anos, entre o final do inverno e início da primavera. Os sistemas de manejo interferiram acentuadamente na produção de forragem, havendo interação entre tratamentos e estações do ano (Figura 1). O tratamento sem queima e sem roço apresentou maior produção de forragem devido a predominância de espécies de hábito ereto, notadamente de Sorghastrum sp.. A área sob queima foi menos produtiva ao longo de todas as estações do ano, totalizando um acúmulo anual de $3.665 \mathrm{~kg} / \mathrm{ha}$ de MS de forragem verde. No entanto, Daubenmire (1968) relatou maiores produções de forragem em áreas queimadas, como decorrência da maior oferta de nutrientes e correção do solo pelas cinzas, redução na competição das espécies invasoras, aumento na diversidade florística da pastagem e através do desenvolvimento de plantas mais eficientes. Em contra partida, verificou-se que a queima sistemática e contínua reduziu drasticamente a produção de forragem. Entre os fatores levantados para essa resposta estão o menor retorno de material morto, cobertura e água no solo; menor teor de bases e maior acidez potencial; além de maior freqüência de espécies pouco produtivas na área queimada, o que pode promover um efeito inverso na produção de forragem (HERINGER; JACQUES, 2002). A maior produção em áreas queimadas pode ser atribuída à eliminação do efeito barreira do acúmulo de material morto e de macega, favorecendo o novo crescimento e o incremento da disponibilidade de forragem verde (WILLMS et al., 1981). Este efeito benéfico é anulado com o avançar do estágio fenológico das plantas. 
COSTA, M.R.G.F. et al. Uso do fogo em pastagens naturais. PUBVET, Londrina, V. 5, N. 9, Ed. 156, Art. 1050, 2011.

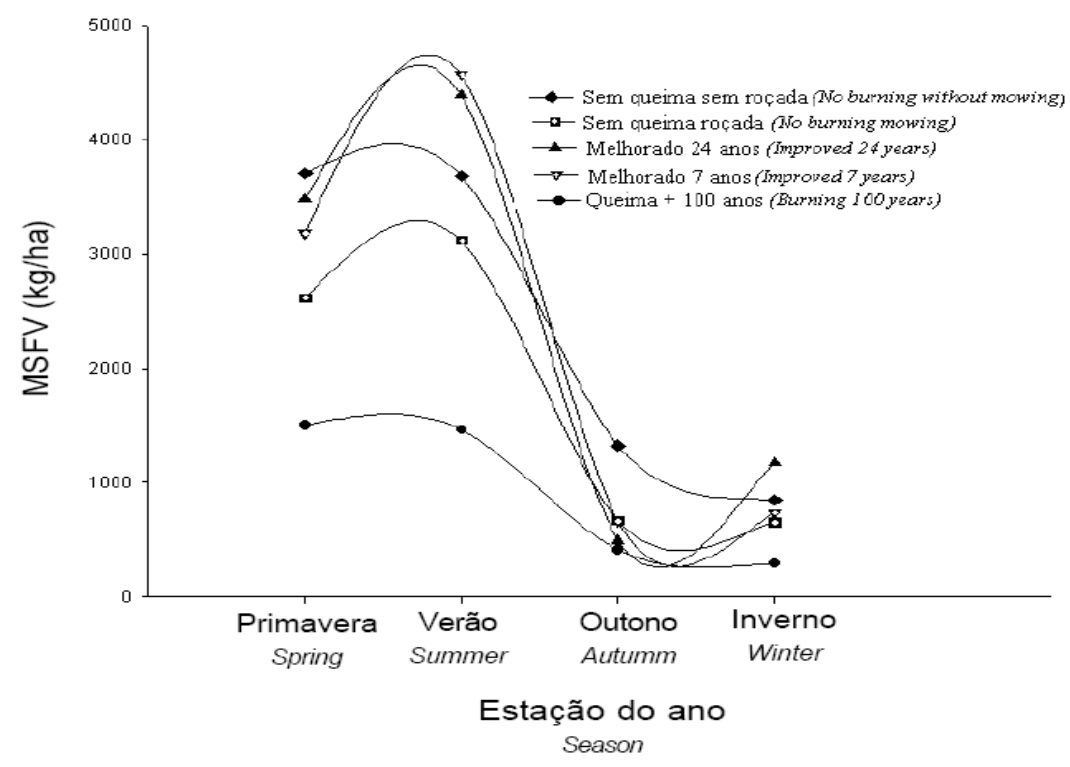

Figura 1. Produção média estacional de forragem de matéria seca de forragem verde (MSFV) em pastagem nativa sob distintos manejos (HERINGER; JACQUES, 2002).

Com relação à qualidade da forragem da pastagem nativa sob uso do fogo, Heringer \& Jacques (2002) relataram que a área queimada apresentou teores de PB inferiores aos obtidos nos outros tratamentos durante a estação quente, porém, sendo semelhante ao tratamento sem queima e sem roçada no período do frio. Os tratamentos melhorados e o sem queima e roçado apresentaram maior digestibilidade in vitro da MO, comparativamente ao não roçado e no queimado. Em geral, a concentração de nutrientes nos tecidos vegetais não foi alterada pela queima. As plantas da área queimada produziram menos, porém mantiveram teores de nutrientes minerais nos tecidos similares ao da área sem queima e sem roçada. A maior qualidade da forragem dos tratamentos melhorados e roçado justifica-se pela contribuição nestas áreas de espécies de gramíneas e leguminosas e à ampla freqüência de Paspalum notatum, uma espécie nativa de boa qualidade, cujo valor agronômico e ecológico precisa ser mais estudado. Evangelista et al. (1999) obtiveram maiores teores de PB em áreas sem queima, os quais foram reduzidos com o aumento da idade de corte. Houve diferença $(P<0,05)$ em relação ao efeito do fogo sobre as qualidades da forragem de acordo com o tipo de solo. No Cambissolo a área sem queima apresentou maior degradabiliade efetiva da PB da forragem, enquanto que para o Latossolo, os resultados foram inversos. 
COSTA, M.R.G.F. et al. Uso do fogo em pastagens naturais. PUBVET, Londrina, V. 5, N. 9, Ed. 156, Art. 1050, 2011.

\section{Desempenho animal em pastagens naturais manejadas com uso do fogo}

Nas mais diversas regiões do globo, a exploração das pastagens naturais quase sempre esteve associada ao uso do fogo, mas em virtude das mudanças climáticas e do aquecimento global, o uso dessa prática vem sendo condenada pelos ambientalistas. O fogo sempre foi um instrumento útil na exploração de pastagens naturais, sendo bastante difundido em regiões como oeste e sul dos Estados Unidos, na América Latina e África, onde o seu uso aparecia rotineiramente como o único meio disponível para manter a produtividade das pastagens (VILLARES, 1966).

O fogo continua sendo utilizado para o controle da vegetação lenhosa, principalmente na expansão das fronteiras agrícolas, fato bastante observado no Brasil, em particular na região amazônica, como ferramenta para derrubada da floresta. Seu uso em pastagens naturais visa principalmente à eliminação do excesso de material morto acumulado sobre o solo (macega) que é um impedimento físico ao desenvolvimento das gemas basilares e sementes, visando estimular novas brotações, bem mais palatável e nutritiva aos rebanhos, podendo beneficiar o desempenho animal nessas áreas.

O desempenho de animais em pastagens queimadas é controverso. Trabalhos mostraram que o efeito pode ser positivo, já em outros o efeito é nulo e no longo prazo é quase sempre negativo. Pizzio et al. (1997) relataram que em pastagens naturais dominadas por espécies cespitosas grosseiras, tolerantes à queima e com grande acúmulo de fitomassa, o fogo pode ser um instrumento útil para controlar as espécies indesejáveis presentes, melhorar a qualidade da dieta, e aumentar a produção animal. Na Argentina, em pastagem natural dominada por Andropogon lateralis, os ganhos anuais por animal passaram de 76 para $107 \mathrm{~kg}$, a partir do uso da queima anual. Angell et al. (1986) observaram que bovinos ganharam ou mantiveram peso em pastagem natural com predominância de Spartina spartinae, severamente queimada e nas áreas onde não houve fogo os animais mantiveram ou perderam peso. Nas áreas queimadas, o maior ganho de peso pode ser explicado pelo fato da espécie dominante ter um baixo valor nutritivo. Semelhantemente Brâncio et al. (1997), avaliando dietas de animais fistulados no esôfago, não observaram diferença $(P<0,05)$ no valor nutritivo das dietas selecionadas pelos bovinos em áreas com e sem queima, mostrando que os animais são capazes de selecionar forragem de qualidade em meio ao material morto em áreas sem o uso do fogo, não justificando o 
COSTA, M.R.G.F. et al. Uso do fogo em pastagens naturais. PUBVET, Londrina, V. 5, N. 9, Ed. 156, Art. 1050, 2011.

uso desta técnica no manejo da pastagem nativa visando ao aumento na produção animal.

Em regiões de clima semi-árido no Texas, observou-se que após a queima das pastagens nativas na primavera, as dietas de novilhos tiveram maior porcentagem de gramíneas e $15 \%$ menos de ervas em relação às áreas não queimadas. O consumo de cactáceas foi maior nas áreas não queimadas, durante o verão e outono posteriores ao fogo, resultando em maior ganho de peso dos novilhos em alguns meses do ano. Os autores justificaram este maior ganho proporcionado pelo maior consumo de cactáceas em virtude destas espécies suprirem parte das exigências dos animais em água e por isso o deslocamento em busca das bebidas foi reduzido, evitando o gasto de energia e conseqüentemente perda de massa corporal (McGINTY et al., 1983).

\section{Efeito do fogo sobre a reprodução de plantas forrageiras nativas}

O efeito do fogo sobre a germinação de espécies de valor forrageiro pode ocorrer de duas formas. Para algumas o efeito é positivo, elevando o poder germinativo após a queima. Para outras, ocorre uma redução na germinação de suas sementes expostas ao fogo. Algumas espécies australianas necessitam do fogo para completar seu ciclo de vida, tendo este um importante papel para quebrar a dormência, permitindo assim a semente germinar e originar uma nova planta (CHENEY; SULLIVAN, 2008). Essas espécies são chamadas de pirrófitas, cujas sementes possuem tegumento impermeável e germinam bem após o fogo, ocorrendo um processo de escarificação física do tegumento (RIZZINI, 1976).

Em espécies lenhosas, geralmente o fogo promove uma redução na produção de sementes, reduzindo a população de plantas, como resultado da queima direta das sementes ainda não completamente formadas. Para as espécies herbáceas o efeito é inverso, aumentando a produção de sementes devido ao aumento de fertilidade do solo com a queima e a diminuição da competição pelas espécies lenhosas. A espécie lenhosa atingida pelo fogo tem uma grande perda nos tecidos de reserva, que são localizados em grande parte no seu caule, que é aéreo. Já em algumas espécies herbáceas o caule é subterrâneo, ficando protegido da ação do fogo e preservando grande quantidade de tecidos de reserva e gemas (OGDEN, 1980).

Outro efeito do fogo sobre a germinação de plantas forrageiras nativas pode ser observado nos cerrados do Brasil central. Após esta prática observou-se um maior 
COSTA, M.R.G.F. et al. Uso do fogo em pastagens naturais. PUBVET, Londrina, V. 5, N. 9, Ed. 156, Art. 1050, 2011.

florescimento das plantas nestas áreas, aparentemente beneficiadas pelo choque térmico e em outros casos favoreceu a reprodução sexuada, promovendo a abertura de frutos e infrutescências (COUTINHO, 1979). Segundo Vogl (1974), a capacidade de se reproduzirem de forma vegetativa observada em muitas gramíneas perenes e arbustos nativos ajudam na ocupação de novas áreas, isso confere a essas espécies vantagens competitivas e ajuda as espécies a sobrevierem a catástrofes, que incluem o fogo. Além disso, plantas que dispõe de órgãos multiplicativos subterrâneos, conseguem sobreviver com mais freqüência, pois estando mais profundos estes órgãos escapam aos efeitos destrutivos do fogo. No Texas, McAtee et al. (1979), utilizando a queima e também corte da gramínea Spartina spartinae, encontraram maior percentagem de plantas com inflorescência em ambos os tratamentos, por ocasião da estação de crescimento, em comparação a áreas sem queima e sem roço.

O efeito do fogo sobre a germinação pode ser controverso, conforme relatado por White \& Terry (1979) que observaram estímulo ao crescimento do colmo reprodutivo em pastagem de Schizachyrium stolonifer pelo uso o fogo, em detrimento da produção forrageira. O pastejo nessas áreas diminuiu a sobrevivência dos perfilhos e a produção de forragem. Para Mattos (1970), os vegetais podem ser divididos em dois grupos com relação à tolerância à queima: pequena resistência, formado por espécies lenhosas, que possuem um colmo lignificado e pontos de crescimento longe do solo; e outro de grande resistência, constituído de espécies herbáceas de colmo rasteiro ou por vezes subterrâneo, com baixo grau de lignificação, com pontos de crescimento próximos ao solo.

Dentre as espécies adaptadas ao fogo, principalmente as gramíneas, podem ser separadas em dois tipos: espécies tolerantes, de rápida regeneração após o fogo, por armazenar maior energia nos órgãos subterrâneos, chamadas "espécies de rebrotamento" e, espécies denominadas "maturação e morte", que produzem muitas sementes resistentes ao fogo, podendo então germinar após o fogo (ODUM, 1988). Após a queima há uma redução na cobertura vegetal do solo, favorecendo a germinação de sementes (MATTOS, 1970). Heringer (1971) concluiu que há necessidade de clareiras para o estabelecimento de novas plantas, as quais só foram encontradas em locais com vegetação bem rala. No entanto, apesar da queima favorecer a germinação de sementes, sua ação continuada pode destruir as plântulas (WRIGHT, 1974). 
COSTA, M.R.G.F. et al. Uso do fogo em pastagens naturais. PUBVET, Londrina, V. 5, N. 9, Ed. 156, Art. 1050, 2011.

O fogo, além de interferir nos processos de propagação, induz as espécies arbustivas a criar dispositivos de defesa que consistem em cascas grossas, revestimento escamoso, rizomas fortes, tubérculos e túnicas (HERINGER, 1971). Gramíneas desejáveis são, em geral, menos adaptadas ao fogo, comparadas às indesejáveis, observando-se a redução de suas freqüências com o uso indiscriminado do fogo. As espécies Enneapogon polyphyllus e E. avenaceus e Digitaria brownii, altamente palatáveis, foram significativamente reduzidas pela queima, enquanto Aristida contorta, uma espécie moderadamente palatável, foi reduzida $(P<0,05)$ pelo fogo (GRIFFIN; FRIEDEL, 1984). Paranastasis (1980) relatou que, em uma pastagem nativa da Grécia, a queima controla o arbusto Sarcopoterium spinosum (L.), nãopalatável, que acumula galhos secos, podendo machucar os animais, e proporciona alta disponibilidade de forragem do estrato herbáceo.

No Texas, a queima promoveu o aumento de produção e palatabilidade de Hylaria mutica, reduziu a copa de Prosopis grandulosa a níveis aceitáveis e a ocorrência de uma planta invasora anual indesejável denominada Xanthocephalum dracunculoides (WRIGHT, 1974) Entretanto, em pastagens queimadas eventualmente, as espécies arbustivas como P. glandulosa, Acacia rigidula e Acacia tortuosa não foram controladas com a queima simples (uma única queima) e queima repetida por cinco vezes, pois retonavam à cobertura anterior à queima após duas estações de crescimento (HAMILTON; SCIFRES, 1982). A redução de espécies palatáveis e o aumento das não-palatáveis nem sempre é um processo simultâneo. Em pastagens naturais canadenses, o fogo manteve a dominância das gramíneas e reduziu o número de espécies lenhosas (ANDERSON; BAILEY, 1980). A resposta das plantas à queima está também relacionada com a época de sua realização, em razão da interação do fogo e dos fatores climáticos (umidade e temperatura) sobre a germinação e, ou, rebrotação das plantas. Essa resposta ainda depende da intensidade do fogo, das condições de crescimento pós-queima e das interações na competitividade interespecífica das espécies do ecossistema.

\section{Indicações para o uso do fogo como ferramenta de manejo de pastagens naturais}

Para uma melhor compreensão do uso do fogo em pastagens naturais é necessário a definição de dois termos distintos: incêndio e fogo controlado. No 
COSTA, M.R.G.F. et al. Uso do fogo em pastagens naturais. PUBVET, Londrina, V. 5, N. 9, Ed. 156, Art. 1050, 2011.

incêndio o fogo se propaga livremente de acordo com a topografia, condições climáticas e principalmente do material combustível, geralmente liberando grande quantidade de energia e atingindo altas temperaturas. Já, a queima controlada consiste no uso controlado do fogo, conduzido dentro de limites pré-estabelecidos de intensidade, a fim de se alcançar certos objetivos no manejo da pastagem, podendo colaborar no combate de espécies indesejáveis e promovendo o desenvolvimento de espécies de alto valor forrageiro (SOARES, 1995).

Para que se obtenha sucesso no uso da queima em pastagens naturais, algumas precauções devem ser observadas. Villares (1966) recomendou isolar a área a ser queimada do restante da propriedade ou de outras propriedades, por meio de estradas, rios, aceiros, etc, para que o fogo se restrinja ao local desejado, evitando incêndio; fazer a queima uns dois dias após uma chuva, para garantir um eficiente umedecimento do solo, visando à proteção das raízes e órgãos subterrâneos das plantas; escolher as últimas horas do dia, onde o frio e o sereno poderão auxiliar no controle das chamas.

A queima deve ser rápida e contra o vento, resultando em efeitos menos profundos sobre o solo (VICENT, 1935). A velocidade dos ventos no momento da realização da queima maior que $7 \mathrm{~km} / \mathrm{h}$ proporciona maior propagação do fogo na vegetação, reduzindo assim a intensidade da queima, porém se a velocidade dos ventos excedem 15 a $20 \mathrm{~km} / \mathrm{h}$ o a queima não é recomendável devido à alta probabilidade do manejador perder o controle sobre o fogo, havendo assim um super aquecimento do solo, prejudicando o desenvolvimento de novas plantas (RALPH, 1980).

Silva (1998) descreveu que existem diversas formas de queima controlada, que podem ser utilizadas com vantagens sobre o uso tradicional. Conhecendo bem cada uma delas, o manejador poderá decidir qual a que melhor se enquadra no seu terreno:

- Queimada central: é feita em terrenos planos, colocando fogo em vários pontos do centro da área, em forma de círculos. Deste modo, a força do fogo será maior na parte central do terreno e facilitará o trabalho do pessoal envolvido nesta tarefa;

- Queimada em faixa a favor do vento: coloca-se fogo a favor o vento, partir da base do aceiro e ao final da área também deve ser feito um aceiro bem feito e largo para evitar que o fogo saia do controle; 
COSTA, M.R.G.F. et al. Uso do fogo em pastagens naturais. PUBVET, Londrina, V. 5, N. 9, Ed. 156, Art. 1050, 2011.

- Queimada contra o vento: esta é a queimada básica. Iniciar o fogo numa extremidade do terreno, de modo que queime ladeira abaixo ou contra o vento;

- Queimada em faixas horizontais: coloca-se fogo contra o vento, a partir da base do aceiro e, em seguida, a favor do vento;

- Queimadas em faixas verticais: o fogo é ateado contra o vento, a partir do aceiro base. Depois se inicia o fogo a favor do vento, lado a lado com a inclinação do terreno;

- Queimada em vegetação dispersa: começar com o fogo contra o vento, lentamente, sempre partindo da base do aceiro;

- Queimada em faixas com fogo contra o vento: é uma maneira fácil e segura de se limpar terrenos, porém é importante observar bem a estabilidade e direção do vento;

- Queimadas por pontos: o fogo é posto contra o vento a partir do aceiro base. Na queimada por ponto tem-se a vantagem de que nenhum fogo vai ser grande nem difícil de controlar;

- Queimadas em cunho a favor do vento: coloca-se fogo, ao mesmo tempo, em vários pontos da borda do terreno, sempre a partir do aceiro- base. Esta prática é recomendada somente para vegetação leve.

Para realizar uma queima controlada ou prescrita é fundamental seguir algumas recomendações, pois ela queima requer um estudo prévio para conhecimento das condições ideais para a sua realização. Verificar com atenção a área a ser queimada, tipo de vegetação, temperatura local, umidade do ar e pessoal disponível. Para evitar perigos futuros é imprescindível queimar, antecipadamente, as acumulações de materiais combustíveis (lenhosos) na linha de controle do fogo Não abandonar, em hipótese alguma, a área incendiada até a completa extinção do fogo. Nas Figuras 2, 3, 4 e 5 são apresentados exemplos de como proceder uma queima controlada e segura para o manejo de pastagens. 
COSTA, M.R.G.F. et al. Uso do fogo em pastagens naturais. PUBVET, Londrina, V. 5, N. 9, Ed. 156, Art. 1050, 2011.

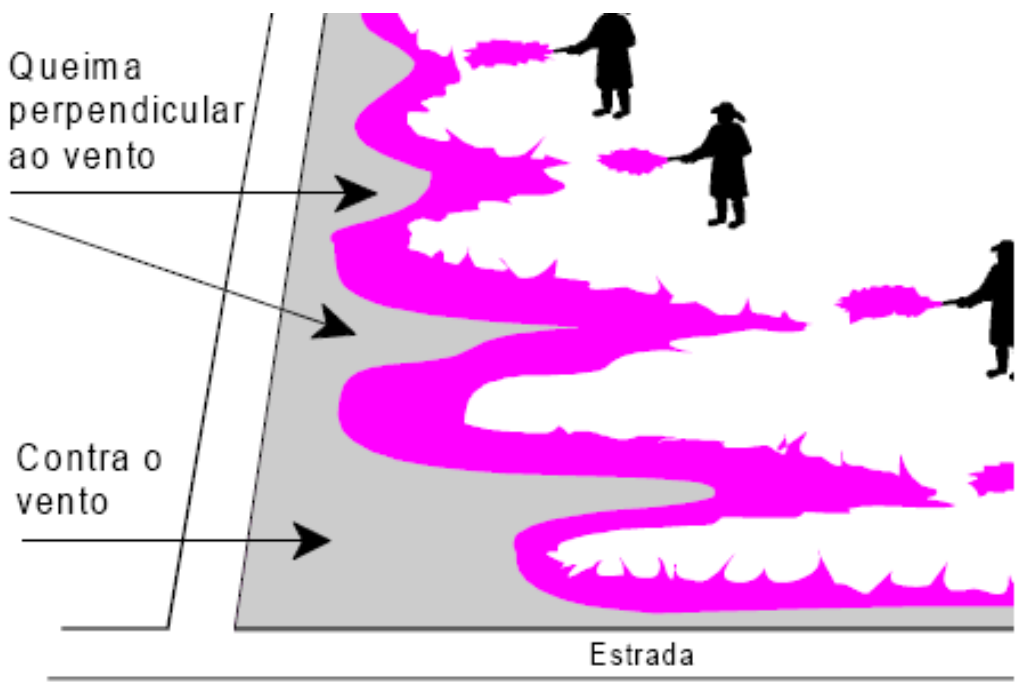

Figura 2. Queima progressiva contra o vento.

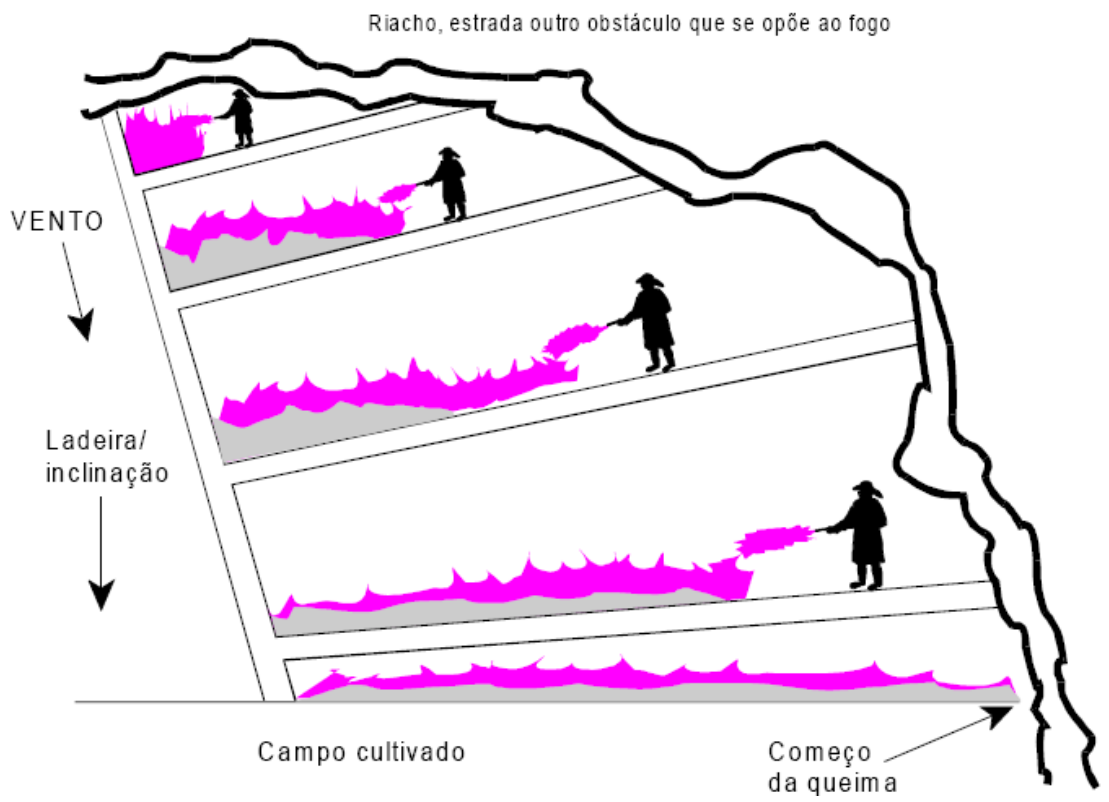

Figura 3. Queima em faixas a favor do vento. 
COSTA, M.R.G.F. et al. Uso do fogo em pastagens naturais. PUBVET, Londrina, V. 5, N. 9, Ed. 156, Art. 1050, 2011.

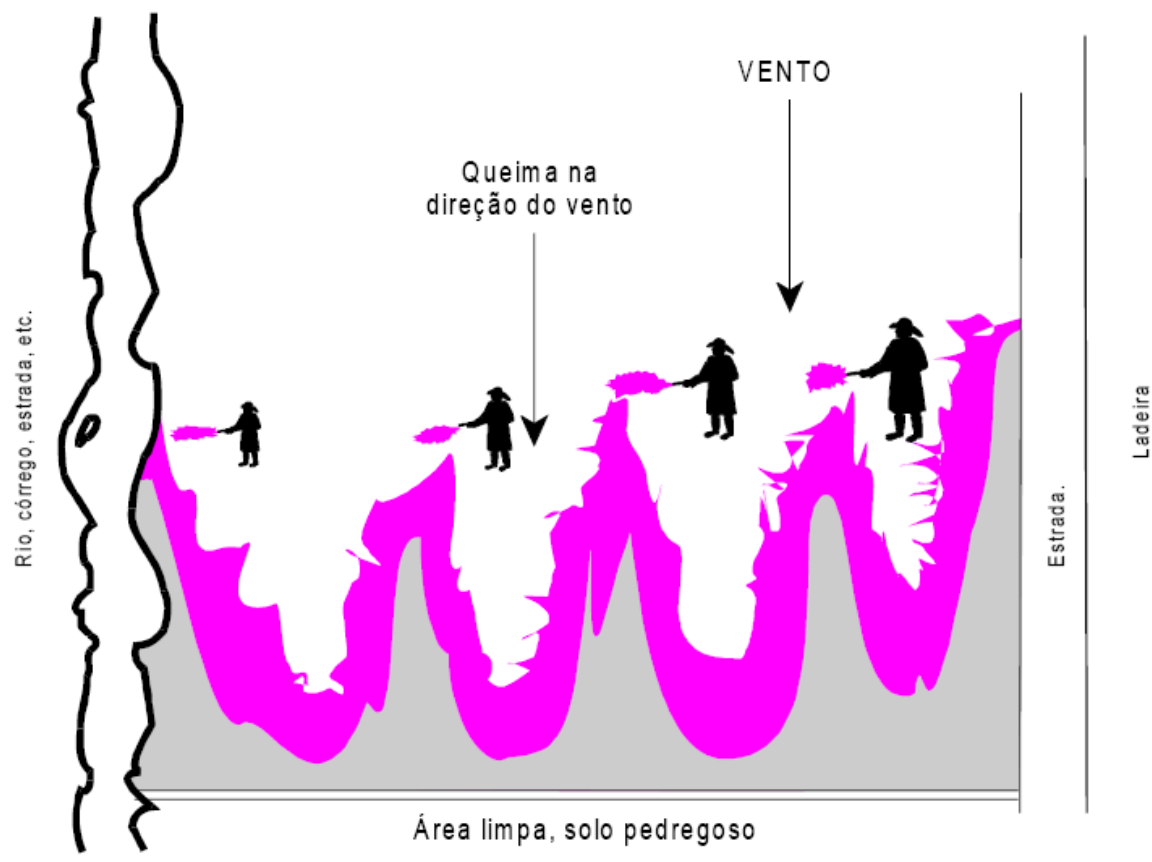

Figura 4. Queima em cunho a favor do vento.

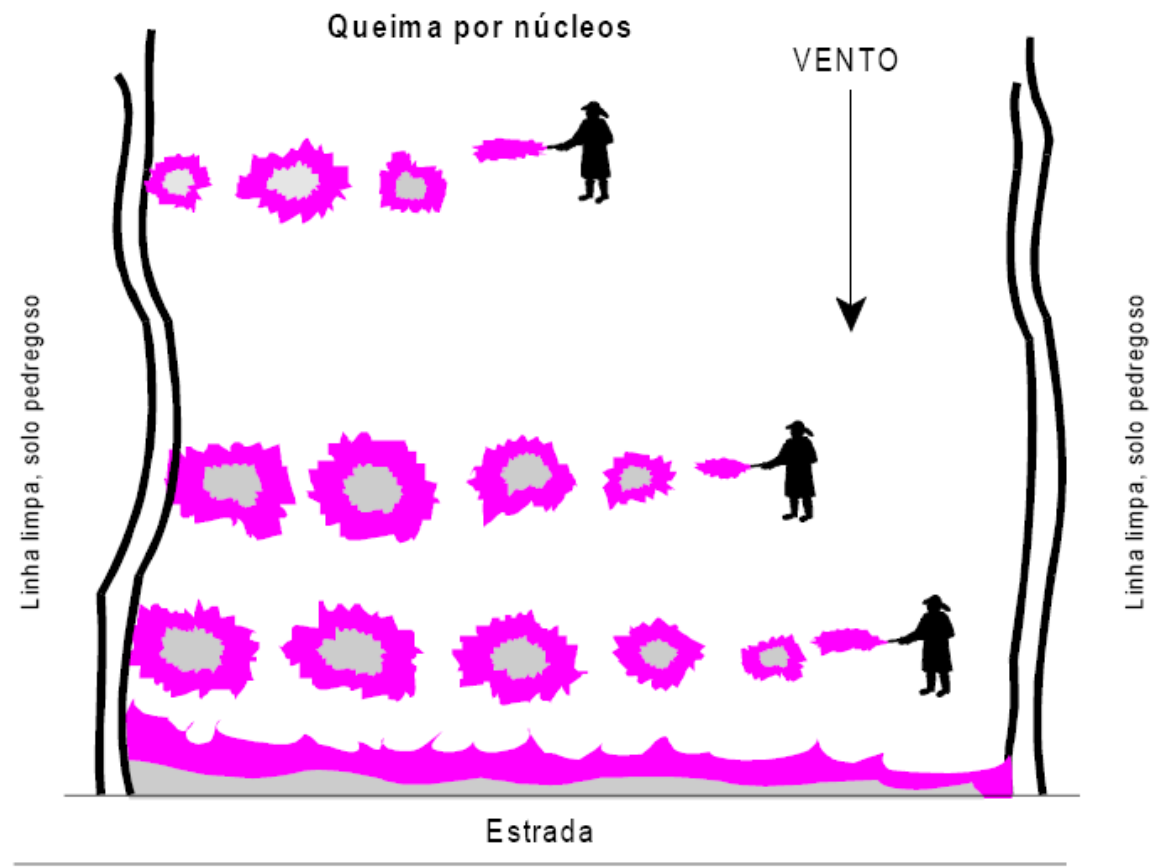

Figura 5. Queima por pontos. 
COSTA, M.R.G.F. et al. Uso do fogo em pastagens naturais. PUBVET, Londrina, V. 5, N. 9, Ed. 156, Art. 1050, 2011.

\section{Considerações Finais}

O uso racional do fogo em pastagens naturais pode ser benéfico para os atributos químicos do solo, proporcionando a mineralização de seus nutrientes e os disponibilizando para as plantas, promovendo assim maior crescimento. Sem os devidos cuidados pode promover uma redução nos teores de MO do solo, fato que reduz algumas qualidades físicas e biológicas.

Em pastagens naturais o uso do fogo nem sempre promove aumento na produção e qualidade da forragem, sendo as respostas relacionadas com a sua composição florística. Quando se tem a presença de espécies com grande valor forrageiro tolerantes ao fogo, essa prática pode ser benéfica quanto à qualidade da forragem, mas, quando as espécies tolerantes ao fogo forem de baixa palatabilidade e baixo valor nutritivo, a qualidade do pasto é reduzida pelo uso do fogo. A ocorrência do fogo em determinadas áreas de pastagens naturais é benéfica para o desenvolvimento de algumas espécies de plantas, pois este age com agente escarificador sobre o tegumento da semente, promovendo a sua germinação.

O desempenho animal, em pastagens naturais queimadas, é uma resposta direta a modificação na qualidade da forragem em virtude da indução do perfilhamento, o que eleva valor nutritivo do pasto, promovendo assim, maior ganho de peso dos animais. Contudo, este efeito pode ser anulado quando há uma modificação no comportamento ingestivo dos animais em conseqüência da mudança florística do pasto natural.

A prática de queimadas em pastagens naturais é arriscada, pois se trata de biomas frágeis e com equilíbrio delicado. Se não forem observados os procedimentos adequados de segurança, a queimada pode sair do controle, dando origem a um incêndio, ocasionando perdas irreparáveis ao ecossistema.

\section{Referências Bibliográficas}

ANDERSON, H.G.; BAILEY, A.W. Effects of annual burning on grassland in the aspen parkland of east-central. Canadian Journal of Botany, n.39, v.58, p.985-996, 1980.

ANGELL, R.F.; STUTH, J.W.; DRAWE, D.L. Diets and liveweight changes of cattle grazing fall burned gulf cordgrass. Journal of Range Management, n.39, v.3, p.233-236, 1986.

ARIAS, P.J. Prós e contras da queima dos pastos. FIR, São Paulo, v.5, n.12, p.47-55, 1963. 
COSTA, M.R.G.F. et al. Uso do fogo em pastagens naturais. PUBVET, Londrina, V. 5, N. 9, Ed. 156, Art. 1050, 2011.

BRÂNCIO, P.A.; NASCIMENTO JÚNIOR, D.; MORAES, E.A. et al. Avaliação de pastagem nativa dos cerrados submetida à queima anual. 2. Qualidade da dieta de bovinos. Revista Brasileira de Zootecnia, v.26, n.3, p.438-442, 1997.

CARDOSO, E.L.; CRISPIM, S.M.A.; RODRIGUES, C.A.G.R. et al. Efeitos da queima na dinâmica da biomassa aérea de um campo nativo no Pantanal. Pesquisa Agropecuária Brasileira, v.38, n.6, p.747-752, 2003

CHENEY, P.; SULLIVAN, A. Grassfires: fuel, weather and fire behavior. $2^{\mathrm{a} e d .}$ CSIRO, 160p. 2008.

COUTINHO, L.M. Aspectos ecológicos do fogo no cerrado: III. A precipitação atmosférica de nutrientes minerais. Revista Brasileira de Botânica, v.2, p.97-101, 1979.

DAUBENMIRE, R. Ecology of fire in grassland. Advances in Ecological Research, v.5, p.209266, 1968.

EVANGELISTA, A.R.; LIMA, J.A. de; CURI, N. Degradabilidade in situ de pastagens nativas em diferentes idades de corte. Ciência e Agrotecnologia, v.23, n.2, p.427-433, 1999.

FERNANDES, A.H.B.M.; FERNANDES, F.A. Características químicas do solo em área de pastagem nativa recém queimada no Pantanal arenoso, MS. Corumbá: Embrapa Pantanal, 2002. 18p. (Embrapa Pantanal. Boletim de Pesquisa e Desenvolvimento, 36).

FERNANDES, F.A.; FERNANDES, A.H.B.M.; CRISPIM, S.M.A. Biomassa microbiana e conteúdos de carbono e nitrogênio do solo em áreas de pastagem nativa sujeita à queimada, Pantanal Mato-Grossense. Corumbá: Embrapa Pantanal, 2007. 22p. (Boletim de Pesquisa e Desenvolvimento, 73).

FERNANDEZ, I.; CABANEIRO, A.; CARBALLAS, T. Organic matter changes immediately after a wild-fire in Atlantic Forest soil and comparison with laboratory soil heating. Soil Biology \& Biochemistry, v.29, p.1-11, 1997.

FRANGI, J.L.; RONCO, M.G.; SANCHES, N.E. et al. Efecto del fuego sobre la composición y dinámica de la biomasa de un pastizal de Sierra de la Ventana (Bs. As., Argentina). Darwiniana, v.22, n.4, p.565-585, 1980.

GIOVANNINI, G.; LUCCHESI, S. Modifications induced in soil physico-chemical parameters by experimental fires at different intensities. Soil Science, v.162, n.7, p.479-486, 1997.

GIRARDI-DEIRO, A.M.; MOTA, A.F.; GONÇALVES, J.O.N. Efeito do corte de plantas lenhosas sobre o estrato herbáceo da vegetação da Serra do Sudeste, RS, Brasil. Pesquisa Agropecuária Brasileira, v.29, n.12, p.1823-1832, 1994.

GRIFFIN, G.F.; FRIEDEL, M.H. Effects of fire on central australian rangelands. I. Fire and fuel characteristics and changes in herbage and nutrients. Australian Journal of Ecology, n.12, v.9, p.981-93, 1984.

HAMILTON, W.T.; SCIFRES, C.J. Prescribed burning during winter for maintenance of buffelgrass. Journal of Range Management, v.35, n.1, p.:9-12, 1982. 
COSTA, M.R.G.F. et al. Uso do fogo em pastagens naturais. PUBVET, Londrina, V. 5, N. 9, Ed. 156, Art. 1050, 2011.

HERINGER, E.P. Propagação e sucessão de espécies arbóreas do cerrado em função do fogo, do cupim, da capina e do aldrim (inseticida). In: SIMPÓSIO SOBRE O CERRADO, 1971, Piracicaba. Anais... Piracicaba: USP, 1971, p.34-57

HERINGER, I. Efeitos do fogo por longo período e de alternativas de manejo sobre o solo e a vegetação de uma pastagem natural. Porto Alegre: UFRGS, 2000. 208p. Tese de Doutorado em Zootecnia.

HERINGER, I.; JACQUES, A.V.A. Acumulação de forragem e material morto em pastagem nativa sob distintas alternativas de manejo em relação às queimadas. Revista Brasileira de Zootecnia, v.31, n.2, p.599-604, 2002

HERINGER, I.; JACQUES, A.V.A.; TEDESCO, C.A.B.M. Características de um Latossolo Vermelho sob pastagem natural sujeita à ação prolongada do fogo e de práticas alternativas de manejo. Ciência Rural, v.32, n.2, p.309-314, 2002

HODGSON, J. Grazing management. New York: Longman Scientific and Technical, 1990. $203 p$.

JACQUES, A.V.A. Sítio do Pinheirinho: uma pequena experiência de 37 anos. RST $470 \mathrm{Km}$ 150, André da Rocha, RS. 2002. 9p. (Relatório).

MATTOS. J.C.A. A influência do fogo na vegetação e o seu uso no estabelecimento e manejo de pastagens. Zootecnia, n.8, v.4, p.45-58, 1970.

MCATEE, J.W.; SCIFRES, C.J.; DRAWE, D.L. Digestible energy and protein content of gulf cordgrass following burning or shredding. Journal of Range Management, v.32, n.5, p.376$378,1979$.

MCGINTY, A.; SMEINS, F.E.; MERRIL, L.B. Influence of spring burning on cattle diets and performance on the Edwards Plateau. Journal of Range Management, v.36, n.2, p.175-178, 1983.

MOORE, A.W. The influence of annual burning on a soil in the derived savanna zone of Nigeria. In: INTERNATIONAL CONGRESS OF SOIL SCIENCE, Amsterdã. Anais... Amsterdã, 1960, p. 142-161.

NARDOTO, G.B.; BUSTAMANTE, M.M. da C. Effects of fire on soil nitrogen dynamics and microbial biomass in savannas of Central Brazil. Pesquisa Agropecuária Brasileira, v.38, n.8, p.955-962, 2003

OGDEN, P. R. Manejo de pastagens nativas enfrentando a variabilidade. In: SIMPÓSIO BRASILEIRO DE MANEJO DE PASTAGENS NATIVAS DO TRÓPICO SEMI-ÁRIDO, 1., 1980, Fortaleza. Anais... Fortaleza, 1980, p.67-82.

ODUM, E. P. Ecologia. Rio de Janeiro: Guanabara. 434p, 1988.

PARANASTASIS, V.P. Effects of season and frequency of burning on a phyganic rangeland in Greece. Journal of Range Management, v.33, n.4, p.251-255, 1980.

PIZZIO, R.; PALLARÉS, O.R.; FERNÁNDEZ, J.G. Pasturas subtropicales en campos bajos de corrientes. Noticias y Comentarios, v.321, 1997. 40p. 
COSTA, M.R.G.F. et al. Uso do fogo em pastagens naturais. PUBVET, Londrina, V. 5, N. 9, Ed. 156, Art. 1050, 2011.

RAISON, R.J. Modification of the soil environment by vegetation fires, with particular reference to nitrogen transformations: a review. Plant and Soil, v.51, p.73-108, 1979.

RALPH, W. Fire in arid rangelands. Rural Research, v.109, p.9-15. 1980.

RHEINHEIMER, D. dos S.; SANTOS, J.C.P.; FERNANDES, V.B.B. et al. Modificações nos atributos químicos de solo sob campo nativo submetido à queima. Ciência Rural, v.33, n.1, p.75-81, 2003.

RIZZINI, C.T. Tratado de fitogeografia do Brasil. São Paulo: Edusp, 1976. 327p.

SACIDO, M.; CAUHÉPÉ, M. Calidad de los rebrotes postquema en pajonales de Paspalum quadrifarium. In: REUNIÓN DEL GRUPO TÉCNICO REGIONAL DEL CONO SUR EN MEJORAMIENTO Y UTILIZACIÓN DE LOS RECURSOS FORRAJEROS DEL AREA TROPICAL Y SUBTROPICAL, 24., 1998, Montevideo. Anais... Montevideo: INIA, 1998. p.73-85.

SCHACHT, W.H.; STUBBENDIECK, J.; BRAGG, T.B. et al. Soil quality response of reestablished grasslands to mowing and burning. Journal of Range Management, v.49, n.5, p.458-463, 1996.

SILVA, R.G. da. Manual de prevenção e combate aos incêndios florestais. Instituto Brasileiro do Meio Ambiente e dos Recursos Naturais Renováveis, 1998.

SOARES, R.V. Queimadas controladas: prós e contras. In: FÓRUM NACIONAL SOBRE INCÊNDIOS FLORESTAIS, 1, 1995, Piracicaba, Anais... Piracicaba: IPEF, 1995. p.6-10.

SVEJCAR, T.J. Animal performance and diet quality as influenced by burning on tallgrass prairie. Journal of Range Management, v.42, n.1, p.11-15, 1989.

VILLARES, J.B. Melhor queimar em etapas. Coopertia, São Paulo, v.23, p.53-54, 1966.

VINCENT, C.A queima dos campos. Revista da Indústria Animal, v.4, p.286-99, 1935.

VOGL, R.J. Effects of fire on grasslands. In: Fire and Ecosystems. Academic Press. New York, p.542, 1974.

WHITE, L.D.; TERRY, W.S. Creeping bluestem response to prescribed burning and grazing in South Florida. Journal of Range Management, v.32, n.5, p.369-371, 1979.

WILLMS, W.; BAILEY, A. W.; McLEAN, A. et al. Effects of fall clipping or burning on the distribution of chemical constituents in bluebunch wheatgrass in spring. Journal of Range Management, v.34. n.4, p.267-269, 1981.

WRIGHT, H.A. Range burning. Journal of Range Management, v.27, n.1, p.5-11, 1974.

WRIGHT, H.A.; CHURCHILL, F.N.; STEVENS, W.C. Effects of prescribed burning on sediment, water yield and water quality from juniper land in Central Texas. Journal of Range Management, v.29, n.7, p.294-298, 1976. 